\title{
Rethinking the Government Role of Promoting Employment Policies for Persons with Disabilities: A Case Study of Anhui Province in China
}

\author{
Xia Luo, Yuting Fan \\ School of Management, Anhui University, Hefei, China \\ Email:1uoxiay@163.com
}

How to cite this paper: Luo, X. and Fan, Y.T. (2017) Rethinking the Government Role of Promoting Employment Policies for Persons with Disabilities: A Case Study of Anhui Province in China. Open Journal of Social Sciences, 5, 209-219.

https://doi.org/10.4236/jss.2017.58017

Received: June 18, 2017

Accepted: August 21, 2017

Published: August 24, 2017

Copyright (c) 2017 by authors and Scientific Research Publishing Inc. This work is licensed under the Creative Commons Attribution International License (CC BY 4.0).

http://creativecommons.org/licenses/by/4.0/

(c) (i) Open Access

\begin{abstract}
Under the backdrop of a slowing global economy and downward pressure on the domestic economy, the Chinese government in 2012 put forward a goal of completing the building of a moderately prosperous society in all aspects, achieving common prosperity for everyone, and promoting social equity and justice. However, a truly prosperous society cannot be completed without taking into consideration people with disabilities. One focus should be on doing everything possible to promote employment opportunities and improve income for the persons with disabilities. Consequently, the Chinese government is interested in finding solutions and developing measures to address the issues of employment for them. This case study utilizes literature research, interviews, and statistical analysis methods to review government policies for people with disabilities in Anhui Province. The government support policies for persons of disabilities are about three main employment forms, human resources development and financial direct support. The article expounds the improper roles of the government such as imperfect implementation of policies, weak interventions by social organizations, limited welfare enterprises, inadequate community and family function development. It also suggests that the government strengthen policies, foster NGOs, and play the role of family and community to improve employment for persons with disabilities.
\end{abstract}

\section{Keywords}

Employment for Persons with Disability, Employment Policies, Government Role 


\section{Introduction}

Employment is of importance for persons with disabilities (PWD), because it could improve their economy condition and self-confidence as well. However, the employment rates of PWD are lower than those of non-disabled in many countries. In the United Kingdom, the employment rate of PWD is $48 \%$, and they are two and half times more likely to be out of work than non-disabled persons [1]. In Australia, Survey of Disability Ageing and Carers (SDAC) shows that only 52.8\% PWD aged 15 - 64 years are in the workforce, and over one million $(47.7 \%)$ are in paid employment, $68.1 \%$ of PWD feel job restrictions as job type, changing jobs or getting a preferred job and work time [2].

In China, low employment rates, high unemployment, low income employment of PWD can be described as three basic characteristics in the current employment situation [3]. The rate of national employment for PWD was 38.7\% [4] in 2015. Under the backdrop of a slowing global economy and downward pressure on the domestic economy, China's Premier stressed the importance of entrepreneurship and innovation in Government Work Report 2015 [5]. In this report, the Chinese government has a goal of completing the building of a moderately prosperous society in all aspects by 2020 .

The Chinese government has made efforts to support employment for PWD by many laws and regulations. There is provision in the Constitution of the People's Republic of China (CPRC) of 2004 like "the State and society help make arrangements for the work, livelihood and education of the blind, deaf-mutes and other handicapped citizens" (the National People's Congress of the People's Republic of China, 2004). There are some special laws and regulations, such as People with Disabilities Act (PDA) of 1990 (Amended in 2008), Regulations on Employment of Persons with Disabilities of 2007 (Legislative Affairs Office of the State Council P. R. China, 2007), Employment Promotion Law (EPL) of 2008 (Amended in 2015), Administrative Measures for the Administration of the Collection and Payment of Employment Security for the Disabled in 2015 are among the regulations. The employment policies for PWD are not only to meet the needs of individual interests, but also relate to the harmonious and sustainable development of the whole society. Achieving full employment for PWD is of great significance of completing the building of a moderately prosperous society. The Chinese government has been making every effort to ensure the employment for PWD, but some researchers point out that the responsibility of public service of employment for PWD should not only be borne by the government [6], some other researchers believe that social welfare-including employment for PWD should be led by the government [7], but this is not enough. So it is essential in this period of social-economic transformation to rethink the role of government in supporting and promoting employment for PWD.

This paper aims to illustrate the government support policies for employment for PWD, discuss the function of government in promoting employment for 
PWD, and explore how the government can play a role in promoting and encouraging the social organizations and disabled families, and ultimately in supporting employment for PWD. This study utilizes literature research, interviews, statistical analysis methods, and takes Anhui (AH) Province as a case.

AH Province is a major agricultural province, most part of PWD live in rural areas where are under development and the public employment services are backward, employment opportunities for PWD are not so optimistic. AH Province is located in the eastern part of China. Its territory is 5.38 square miles, $1.5 \%$ of the total country. The provincial capital is Hefei City. At the end of 2015, its registered population was 69.5 million, and the urbanization rate was $50.5 \%$. AH Province is a big agricultural province of China, the GDP of 2015 was $¥ 2200.5$ billion and per capital GDP was $¥ 35,997$, annual revenue of $¥ 401.2$ billion, of which $¥ 254.4$ billion is local finance income.

\section{Status Qua: Policies of Government Supports}

According to the CPRC and Labor Law, PWD have the same labor rights as other labor-aged people. The Chinese government has been implementing policies to support employment for PWD since 1980s, especially since China Disabled Person's Federation (CDPF) was established in 1988, and Anhui Disabled Person's Federation (ADPF) was established as other provincial organizations in the same year. It is clearly defined provisions in PDA, EPL and other regulations on government support for the employment for PWD in three areas: 1) three forms of work placement employment support, 2) human resources development support, and 3) financial support. The follows illustrate the status qua of those polices in AH Province.

\subsection{Three Forms of Employment Support Policies}

China has adopted policies of three main forms of employment support for PWD: 1) quota employment, 2) collective employment, and 3) flexible employment.

Quota employment policy to promote employment of PWD as a percentage of the workforce has been implementing in China since 1990 and AH Province also adopted the policy in 1994. The policy stipulates that all employers, including government and government-affiliated institutions and entrepreneurs must provide jobs for the disabled at the percentage of no less than $1.5 \%$ of their total number of employees [8]. If any employer does not meet the predetermined $1.5 \%$, it must make a payment to the Employment Security Fund (ESF) for PWD annually, which is used for the benefit of the disabled including employment support and other forms of assistance. The amount of payment is calculated by the following formula: (the amount of employees $\times 1.5 \%$-the actual amount of placement jobs) $\times$ the average salary of the employees in the previous year. The ESF fund can be used by different level organizations of DPFs. The ADPFs 
raised ESF more than $¥ 300$ million in 2014. Through government budget management, the ADPFs may use this fund to promote employment for PWD in many ways including education and training, vocational rehabilitation and so on.

Collective employment for PWD is the second form of employment. The AH provincial government enacted regulations to improve some organizational capacity to provide collective jobs for PWD in 2007. According to these policies, Blind Person Massage Institutions, welfare entrepreneurs and other institutions can provide PWD with a number of jobs. The government deducts taxes or gives capital support to the organizations supervision, identification and protects the legitimate rights and interests of workers with disabilities. Since 2015, ADPF has been implementing Regulations on the Employment for People with Disabilities, Opinion on the Development of Secondary Employment for People with Disabilities and the provincial government enacted Opinion on the Promotion of Persons with Disabilities Family Income and Accelerate the Pace of Well-off and relevant regulations, comprehensively promote assistive employment and wealth collective forms of employment for the PWD.

Flexible employment is the third form of employment support for PWD. The government has many public policies to support and stimulate the employment for PWD. AH Province government issued AH Province Million Employment Support Program in 2012, which has been implementing since then. AH Province started the Three-year Action Plan of Business and Employment of Persons with Disabilities in AH in 2015. It encourages PWD to run businesses by themselves and offers $¥ 2000$ subsidies to each self-employed PWD. It also put forward the plan of helping 10,000 disabled job seekers to get jobs. The Sunshine Disabled Employment Base for Poverty Alleviation is a part of the program in rural areas, through which the government provides 1000 "Sunshine greenhouses" and other facilities and agricultural projects for PWD living in rural area. The government also provides subsidies for individual entrepreneurship.

All these policies have promoted employment for PWD. A research based on survey was conducted in $\mathrm{AH}$ province to learn if employment related policies and implementation of these policies of the employment for the disabled were of value in promoting employment for PWD [9].

\subsection{Human Resources Development Support Policies}

The AH provincial government not only directly supports and promotes the employment for PWD in its policies and regulations, but also pays attention to human resources development for PWD to improve their ability to achieve employment by means of vocational training, vocational rehabilitation, education. With the government goal of increasing skills of current and potential workers, a series of policies to strengthen vocational skills training for PWD have been issued and implemented by DPFs and some other institutions. AH Province built 
144 vocational training bases by the end of 2014, which have trained 34,482 PWD, including 12,000 in urban areas. The blind massage skill training programs are specific to blind people. There are health care massage training programs and medical care massage training programs which have trained about 8000 trainees in total. In 2014, four livelihood projects were added, including employment promotion project. These provide public service jobs, for college graduates; employment trainee subsidies; and other forms of employment support to help disadvantaged groups. The project for poverty relief and rehabilitation for PWD continues to be implemented. In addition, the local government responds positively to "Internet+" flexible employment and welfare activities which were proposed by ADPF. More than 300 PWD gain "Internet+" vocational training through on-line learning and training in AH Province per year.

In addition, the government is also concerned with educational rights for PWD. There are 66 special education schools in AH Province in 2014, including one provincial special education college built in 2008, which is a vocational college for cultivating career opportunities for PWD. This school enrolls students with hearing, vision, and physical disabilities to develop skills such as computer application, costume design, arts and crafts, massage, electrical and electronic applications, and maintenance. 1061 college disabled students have finished this kind of diploma education and over 7000 PWD have gained short-term or medium-term vocational training from this provincial special education college. The rate of employment for graduates and trainees is above $90 \%$.

On top of this, AH Province has implemented the "Measures Funded Education for Higher Education for Disabled Students from Poor Families Program". The government provides a one-time funding to full-time college students with disabilities with $¥ 1500$ per disabled college student per year, and $¥ 2500$ per graduate; b) adult higher education disabled graduated students after they obtain the corresponding qualification certificate with $¥ 4000$ or $¥ 5000$. Through these education supports, the poor disabled students can obtain equitable formal high education without being affected by poverty. Ultimately, education and vocational training develop skills and knowledge should make employment for them much easier.

\subsection{Financial Support Policies}

Financial subsidies are one way the government supports employment for PWD. There are usually 4 kinds:

1) A one-time subsidy of $¥ 2000$ for individual disabled entrepreneurs according to the "A Million Disabled People in Employment Support Program";

2) To give financial loans according to A Rehabilitation and Poverty Alleviation Loan Management Reform Opinions of 2008, whose purpose was to fully enhance the efficiency in the use of rehabilitation loans for poverty alleviation, 
and to support the impoverished disabled with food and clothing. In 2015, the Three-year Action Plan of Business and Employment for Persons with Disabilities in AH continued to implement the policy which supplies grants for low-income families of the disabled and provides credit support to the disabled poor base, employment support and entrepreneurship support for PWD through small home loans;

3) To provide financial support to impoverished disabled college students; and

4) To provide incentives to employers who hire more than the required $1.5 \%$ of PWD. The employer can get subsidy of $¥ 2000$ for each disabled employee.

\section{Problems: The Improper Role of the Government}

While the government plays an important role in promoting employment for PWD, and has achieved some success, there have been some problems as well with the government involvement.

\subsection{Imperfect Implementation of Policies}

There are three aspects to this imperfect implementation:

1) Misappropriation of funds. For instance, the ESF is a special fund to promote employment for PWD. It turned out that it was used to do lots of other things instead of employment for PWD [10]. In 2014, the total expenditure of AH Provincial ESF is $¥ 77.8$ million, but only $15.1 \%$ of it was on employment and training and $0.07 \%$ on rehabilitation, the rest of the fund was spent on other related items [11].

2) Some policies are imperfect even vacant. Take tax reimbursement policy as an example, the welfare enterprises get tax reimbursement no more than $¥ 35,000$ for hiring one disabled employee, which is for subsidy of salary, social security and so on. The welfare enterprises cannot get more subsidies from the government, so they have low enthusiasm to register as welfare enterprises. Besides the imperfect policies, there are no universal elementary education policy yet, no specific policy of fighting against employment discrimination and accessibility to work place and transportation for PWD in many small cities, especially in the rural areas in AH Province. This reflects the government's role is improper. It should have spent more money on the public services to improve universal accessibility and more public jobs.

3) Many policies have implementation problems. Some of the employers won't provide the job for PWD, nor pay for the employment security fund, but then go unpunished [12]. Although the regulations encourage PWD to get a job or run a business, lots of employers refuse the disabled job seekers because of their well-being conditions. Some disabled job seekers cannot get vocational training opportunities or get employment subsidies from the government, because they don't know the policies at all. The weakness of implement force of the government and being lack of social workers in this field affect the result of the employment for PWD. 


\subsection{Weak Interventions by Social Organizations.}

The DPF is a kind of non-profit organization (NGO), but it is actually a governmental agency, because the employees get salary from the government budget and almost $90 \%$ of the running fund raised by the government. This is good for implementation of certain policies from up to the ground, because there are networks of ADPFs and every town has 1 position for this work, plus there are many affiliated public institutions like Employment Service Centers for PWD, which deliver services for disabled job seekers. However those are public sectors, so they are limited by the scale of employees. Thus the limited staff can't advocate the policies well. On the other hand, the government doesn't focus on fostering other NGOs in this field. Only depending on DPFs and their affiliated institutions to provide adequate services for employment and entrepreneurship for PWD is difficult, because there are not enough advocate working for the disabled job seekers.

\subsection{Limited Welfare Enterprises Development}

Welfare enterprise is a special job benefit for PWD, which gets financial or tax support from the government on condition that it must hire above 30\% PWD in its total employees. But the amount of welfare enterprise has shrunk severely in recent years, which led to the amount of disabled employees decreasing dramatically, from 6187 in 2013 to 1604 in 2014 as shown in Table 1. The procedure of establishing a welfare enterprise is complicated, and the scope of the business of welfare enterprises is strictly limited. As a market entity, the development of welfare enterprises is difficult because they must face brutal competition, which causes many welfare enterprises to be on the verge of collapse [13]. Sheltered employment is not organized well because there are lack of practical incentives policies. In addition, although the blind massage businesses are prosperous, the sizes of the enterprises are small. All these affect the efficiency of collective employment.

\subsection{Inadequate Community and Family Function}

The government hasn't given full play to the strength of communities and

Table 1. The increased employment for PWD in AH Province 2010-2015.

\begin{tabular}{ccccccc}
\hline Year & $\begin{array}{c}\text { Total } \\
\text { increased } \\
\text { employment }\end{array}$ & $\begin{array}{c}\text { Increased } \\
\text { collective } \\
\text { employment }\end{array}$ & $\begin{array}{c}\text { Increased } \\
\text { proportional } \\
\text { employment }\end{array}$ & $\begin{array}{c}\text { Increased } \\
\text { flexible } \\
\text { employment }\end{array}$ & $\begin{array}{c}\text { Increased } \\
\text { public } \\
\text { service jobs }\end{array}$ & $\begin{array}{c}\text { Increased } \\
\text { auxiliary } \\
\text { employment }\end{array}$ \\
\hline 2010 & 12,782 & 3323 & 3295 & 6164 & - & - \\
2011 & 14,182 & 2753 & 3134 & 7155 & 1140 & - \\
2012 & 14,969 & 3971 & 3987 & 6073 & 535 & 403 \\
2013 & 33,901 & 6187 & 4280 & 22,316 & 490 & 628 \\
2014 & 8364 & 1604 & 1752 & 4558 & 226 & 224 \\
2015 & 9496 & 1343 & 1882 & 5851 & 197 & 223 \\
\hline
\end{tabular}

Note: The data in the above table is from the report of CPDF 2015. “-” means no data collected. 
families. On the one hand, there are few programs of employment for PWD conducted in communities. As a matter of fact, community has a better understanding of the situation of PWD which can make it easier to address the issues of employment. On the other hand, disabled families have not played encouraging roles either. Whether the families support their disabled kinfolks for capital or spiritual encouragement is an essential determinant of PWD going out to get a job or starting to run a private business. One reason is that families think their kinfolks who have physical disabilities could not be capable of working and even should not go out in "spotlight" to avoid of being bullied. Another reason is that the incomes of disabled families are generally under the poverty line, which is an obstacle for the families to support the disabled kinsfolk for running a small business, for they cannot endure the risk of investment [14]. Developing policies are needed to encourage the community and family to support employment or running businesses by PWD.

\section{Countermeasures: Adjusting the Position of Government}

Rethinking the government role in supporting and encouraging employment for PWD, some measures must be taken to adjust the government role including strengthening policy and encouraging social supports, including the support from NGOs, welfare enterprises, families and communities.

\subsection{Strengthen Policies}

The government could strengthen the power of policies for improving employment for PWD through three steps:

1) Improve and perfect the imperfect policies. As mentioned above, there are some imperfect policies like the tax reimbursement is low for the welfare enterprises, the misappropriate of ESF, adjust and improve the policies of financial support. As the old proverb says, "You give a man a fish and you feed him for a day; teach a man to fish and you feed him for a lifetime." Teaching PWD with fishing skill is much more important than just giving them fish. Turning some subsidies into productive materials or training skills to improve their human resources may make a lifetime of difference [15].

2) Make new policies to protect PWD rights of inclusive education, equal employment without discrimination, accessible work environments and transportation.

3) Advance implementation of policies to change the situation of policies that have not been efficiently implemented [16]. This requires that the policies should be combined with local characteristics of AH Province, such as provide diverse careers training to meet the employment needs of the big part of PWD living in remote rural areas and enforce policy advocacy for rural PWD. It also requires establishing related monitoring mechanisms, such as combine the rate of employment for PWD with the performance-related pay for the employees of DPFs and their affiliated institutions to ensure the efficiency of the policies. 


\subsection{Foster NGOs}

NGOs are one of the most important resources of social support. Because they can eliminate the gap between the public sectors and private sectors, they are much more flexible and can provide diverse services for the needy. The government needs to take steps to foster more NGOs to intervene in supporting employment for the PWD to change the current situation that public employment services are only provided by insufficient public employees. According to international experiences, NGOs can help PWD to get jobs, provide services with vocational training, special education, and advocate protecting their rights in all aspects. What's more, NGOS can act as a bridge between employers and PWD to communicate in a timely and reasonable manner, and express the opinions and ideas of PWD as well [17]. In addition, the-two-face organization of DPF should play an active role to foster other NGOs to cooperate in the cause of employment for PWD.

Cultivate welfare enterprises. Welfare enterprises are stipulated to provide no less than 30\% jobs for PWD according current policy, so cultivating welfare enterprises is an important form of improving employment for PWD. Therefore, the government needs to incense welfare enterprises to develop instead of cutting down the enterprises' welfare, and strengthen the management of sheltered enterprises [18]. Meanwhile the ADPF could find ways to get the most of ESF to cultivate more welfare enterprises to develop.

\subsection{Play the Role of Family and Community}

PWD currently live and work depending on families and communities compared with others. The government needs to provide subsidies loan for the needy families to run family business with PWD and to buy public service jobs in the community for PWD. In addition, the government needs to propagate the importance of employment to PWD, especially change the family's opinion of the workforce of the disabled via media and social workers. Government interacts with family and community to explore more effectively ways of addressing the needs of the employment for the PWD. The government, through programs like Community 10,000 PWD Employment Support Program, Community Rehabilitation Program and Friendly Community Construction Demonstration Program, could make communities more helpful and accessible and therefore produce more employment opportunities for PWD.

\section{Conclusion}

Achieving the goal of a moderately well-off society is the responsibility of the whole country and society. Although the government has done a lot to support and promote employment and entrepreneurship for PWD, to some extent, the function of it is missing in some aspects and offside in some other aspects. So the government needs to adjust its role of improving employment for PWD. Do what it should do, don't do what it should not. It should perfect and strengthen 
its public service function such as inputting more in accessible facilities and professional training for PWD, and improve its implement force as well. Policymakers must integrate social resources to help PWD get jobs or run businesses, through labor supply policies, like employment training, job placement, work supports; labor demand policies, like stimulating labor demand through private approaches, public job creation, equal employment opportunity, and regulatory laws.

\section{References}

[1] Keen, S. and Oulton, R. (2009) Disability Discrimination in Employment. Oxford University, New York.

[2] Australian Bureau of Statistics (2015) Disability and Labor Force Participation (No. 4433.0 55.006).

http://www.abs.gov.au/ausstats\%5Cabs@.nsf/0/C7C72D7706E9BED0CA257DE2000 BDC60?Opendocument

[3] Zhou, L.G. (2011) Study on Construction of Social Security System and Sublic Service System of the Handicapped. China Population Science, No. 2, 93-101.

[4] Calculate According to the Data from National Bureau of Statics (NBS), China Disabled Persons' Federation, et al. The Population of Chinese People Aged 15 - 59 Is 992.5 Million, Accounting for $67.3 \%$ of the Total Population. The Total Population of PWD Is 85.0 Million. So There Are Around 57.2 Million PWD in Labor Age (15 59), But There Are Only 21.08 Million (4.3 Million Work in Urban, 16.8 Million Work Force in Agriculture) PWD Get Jobs. Therefore, the Rate of Employment for PWD Is about $36.8 \%$, and 79.6\% PWD Jobs Are in Agriculture.

[5] Li, K.Q. (2015) Government Work Report: At the Third Session of the Twelfth National People's Congress.

http://www.guancha.cn/politics/2015_03_17_312511.shtml

[6] Wang, Q.Y. and Tan, Z.L. (2006) Study on the Social Security of the Disabled. China Civil Affairs, No. 7, 20-24.

[7] Li, Z.M. and Xu, Y. (2010) Establishing a New View of the Disabled and Promoting the Social Participation and Integration of the Disabled. Social Security Research, No. 1, 105-108.

[8] Xiang, Y.F. (2013) Investigate Job Placement of Persons with Disabilities in Proportion in China. Social Welfare (Theory), No. 5, 39-43.

[9] Luo, X. and Lan, Y. (2015) An Empirical Study on the Factors Influencing the Employment of People with Disabilities: Based on a Survey of Anhui Province. Journal of Anhui Agricultural University (Social Science Edition), 24, 80-85.

[10] Wu, J. (2014) A Research of Employment Security for Persons for Disabilities in Anhui Province. Master's Thesis, Anhui University, Hefei, China.

[11] Anhui Disabled Persons' Federation (2015) Final Accounting of Revenue and Expenditure 2014.

http://www.ahdpf.org.cn/ahcl/infodetail/?infoid=8c5db17c-acb6-4662-8f1e-b2fe3b8 b41e7\&categoryNum $=003007$

[12] Sun, D. (2013) Study of Present Situation of Disability Employment and Promotion Strategies. Master's Thesis, Hubei Correspondence University, Wuhan.

[13] Fan, N. (2010) Dilemma of Employment for Disabled Causes and Solutions: Based on the Employment Policy of Persons with Disabilities in China. Master's Thesis, 
Northwestern University, Xi'an.

[14] Fu, C.W. (2013) Promotion of Employment of Persons with Disabilities Research. Master's Thesis, Shandong University of Finance and Economics, Jinan.

[15] Ji, Y.M. (2014) Employment Situation of Persons with Disability and Countermeasures in Guangdong Province. China Disabled Persons, 2, 46-47.

[16] Yu, M. (2011) Study of Disability Employment Policy and Enforcement Problems. Master's Thesis, Normal University, Nanjing.

[17] Zhou, H.B. and Luo, X. (2015) Research of Employment Service for the Disabled with the Third Sector Participation. Journal of Changchun University, 25, 41-44.

[18] Peng, Y.Y. (2011) Y City Enterprises Job Placement of Persons with Disabilities. Master's Thesis, Nanjing University of Technology and Engineering, Nanjing.

Submit or recommend next manuscript to SCIRP and we will provide best service for you:

Accepting pre-submission inquiries through Email, Facebook, LinkedIn, Twitter, etc. A wide selection of journals (inclusive of 9 subjects, more than 200 journals)

Providing 24-hour high-quality service

User-friendly online submission system

Fair and swift peer-review system

Efficient typesetting and proofreading procedure

Display of the result of downloads and visits, as well as the number of cited articles

Maximum dissemination of your research work

Submit your manuscript at: http://papersubmission.scirp.org/

Or contact jss@scirp.org 